\title{
Serum enzyme changes, muscular dystrophy and erythrocyte abnormalities in lambs fed on diets containing cod-liver oil and maize oil, and the therapeutic effect of vitamin $E$
}

\author{
By J. W. BOYD* \\ Biochemistry Department, ARC Institute of Animal Physiology, \\ Babraham, Cambridge
}

(Received $3 \circ$ August 1967-Accepted 12 fanuary 1968)

\begin{abstract}
I. Lambs fed on skim milk containing either maize oil or cod-liver oil or both were observed for signs of muscular dystrophy, changes in serum enzymes and increases in the susceptibility of red cells to haemolysis by peroxide (peroxide haemolysis).

2. Four lambs fed on the milk containing cod-liver oil, and not receiving $\alpha$-tocopheryl acetate injections, developed acute muscular dystrophy, but no abnormal changes occurred in peroxide haemolysis, packed cell volume or haemoglobin concentration in the blood. Marked increases occurred in the aspartate transaminase, alanine transaminase and glutamate dehydrogenase, and in lactate dehydrogenase isoenzyme activities of the serum, presumably due to leakage from the degenerating tissues. Onelamb given weekly injections of roo mg $\alpha$-tocopheryl acetate remained clinically normal and maintained normal serum enzyme levels. Treatment of dystrophic animals with $200 \mathrm{mg} \alpha$-tocopheryl acetate by injection produced prompt clinical recovery and an exponential decline in the raised serum enzyme activities.

3. In the five lambs fed on the skim-milk containing maize oil, muscular dystrophy did not occur. Small but significant increases occurred, however, in serum aspartate transaminase and glutamate dehydrogenase activities. In all five animals peroxide haemolysis was greatly increased, but in only two did packed cell volume and haemoglobin values fall slightly below the lower limit of normal (mean $-2 \times \mathrm{SD}$ ). Injections of 100-200 $\mathrm{mg} \alpha$-tocopheryl acetate neither prevented nor cured the abnormally high levels of serum enzymes and peroxide haemolysis, although a change in the diet was followed by a gradual return to normal. In one lamb given massive doses of $\alpha$-tocopherol by mouth, peroxide haemolysis was not reduced. Large amounts of $a$-tocopherol added in vitro to erythrocytes from the lamb did, however, prevent peroxide haemolysis.

4. Peroxide haemolysis did not increase in any of three lambs fed on skim milk containing both maize oil and cod-liver oil, although two of them, which were given much larger amounts of cod-liver oil than the third, developed muscular dystrophy with elevated serum enzyme levels.

5. Peroxide haemolysis in lambs is evidently not a measure of vitamin $\mathrm{E}$ deficiency. It is suggested that increased peroxide haemolysis in lambs, like encephalomalacia in chicks, depends on the fatty acid composition of the unsaturated lipids in the diet.
\end{abstract}

Harris \& Embree (1963) analysed the information in published reports of the production of vitamin $\mathrm{E}$ deficiency in experimental animals. Their analysis showed that muscular dystrophy developed when the ratio of vitamin $\mathrm{E}$ to polyunsaturated fat in the diet was low. However, in human subjects maintained on such diets there are no signs of muscular dystrophy. The most consistent finding in man is an increased susceptibility to in vitro haemolysis by peroxide (Horwitt, Harvey, Duncan \& Wilson, 1956). Although anaemia does not occur in adults, decreased erythrocyte survival times have been reported by Horwitt, Century \& Zeman (1963). Furthermore, Hassan,

* Present address: Department of Physiology and Pharmacology, Ontario Veterinary College, University of Guelph, Guelph, Ontario, Canada. 
Hashim, Van Itallie \& Sebrell (1966) observed oedema, skin lesions and increased sensitivity to peroxide haemolysis accompanied by anaemia in human infants fed on a milk mixture with a low ratio of vitamin $\mathrm{E}$ to polyunsaturated fat. The present investigation was undertaken to find out if increased susceptibility to peroxide haemolysis occurred in lambs fed on milk containing either maize oil or cod-liver oil, and if acute muscular dystrophy with raised serum enzyme levels would occur in lambs on the maize-oil diet as it did in lambs on the cod-liver oil diet in previous work (Boyd, 1964). The effect of parenteral administration of $\alpha$-tocopheryl acetate was examined in some of the experimental animals.

\section{EXPERIMENTAL}

Animals. The sixteen animals used were Clun Forest lambs 4-13 days of age when the experiments began. Lambs $190,19 \mathrm{I}$ and 192 were triplets and lambs $I$ and 2, 5 and 6,68 and 69,81 and 82,84 and 85,188 and 189 were twins. As far as possible siblings were given different diets. They were housed, bedded on sawdust, bottle-fed to appetite three times a day and weighed once or twice a week.

Since growth rates were linear during the experiment, linear regression lines were fitted to the values for the weight of each group of lambs. The $t$ test was used to determine the statistical significance of differences between the regression coefficients for weight changes in the different groups of lambs.

Diets. The first group of lambs (nos. 6, 84, 85, I88 and r89) was fed on skim milk containing cod-liver oil. Skim-milk powder, $20 \%(\mathrm{w} / \mathrm{v})$, and cod-liver oil, $5 \%(\mathrm{v} / \mathrm{v})$, were homogenized with warm water just before feeding.

The second group of lambs (nos. I, 65, 8r, 82 and 190 ) was fed on skim milk containing maize oil. This milk was $25 \%(\mathrm{w} / \mathrm{v})$, in warm water, of a proprietary baby food (Olac; Mead Johnson and Co., Evansville, Indiana, USA) made from skim milk and stated to contain maize oil ( $19 \%$ of dry weight) and 33.5 i.u. vitamin $\mathrm{E}$ per $\mathrm{kg}$.

A third group of lambs was fed on skim milk containing both maize oil and codliver oil. One lamb (no. 69) was fed on milk containing $25 \%$ (w/v) Olac and $0.5 \%$ $(\mathrm{v} / \mathrm{v})$ cod-liver oil. Lambs 68 and 192 were given $20 \%(\mathrm{w} / \mathrm{v})$ Olac and $5 \%(\mathrm{v} / \mathrm{v})$ cod-liver oil.

The control group consisted of lamb no. 19r, which suckled its dam, and nos. 2 and 5 which were bottle-fed with $20 \%$ (w/v) milk replacer (Ewbol Orphan Lamb Feed; Lever's Feed Ltd, Birkenhead, England) containing saturated fat $(7 \cdot 25 \%$ of dry weight).

Treatment with vitamin $E$. All the lambs in the first group were treated with vita$\min E$ as described below. No untreated controls were kept since untreated animals were studied in a previous experiment (Boyd, 1964).

In the second group two lambs selected at random (8I and 190$)$ were kept as untreated controls and three lambs ( $\mathrm{I}, 82$ and 65 ) were given vitamin $\mathrm{E}$ as described later.

Serum enzymes. Serum activities of alanine transaminase ( $\mathrm{AlT})$ were determined colorimetrically, and aspartate transaminase (AspT), glutamate dehydrogenase (GDH) and lactate dehydrogenase (LDH) were determined spectrophotometrically 
by the methods described by Boyd (1964). The isoenzymes of lactate dehydrogenase were separated by agar gel electrophoresis, stained by lactate-tetrazolium mixture (Boyd, 1964) and determined by using a recording densitometer (Boyd, 1967). The enzyme units $(\mathrm{U})$ are defined as the $\mu$ moles of coenzyme or substrate transformed per min at $25^{\circ}$. Serum activities are expressed in units per 1 .

Peroxide haemolysis test. To determine the susceptibility of erythrocytes to haemolysis by hydrogen peroxide the method of Rose \& György (1952) was modified to allow for methaemoglobin formation. The cells of $0.5 \mathrm{ml}$ heparinized blood were washed twice with 9-Io $\mathrm{ml} 0.9 \% \mathrm{NaCl}$ buffered with $5 \mathrm{~mm}$-Tris-Tris hydrochloride ( $\mathrm{pH} 7.5)$. They were resuspended in buffered saline to a final volume of ro ml. Portions, $0.25 \mathrm{ml}$, of the blood-cell suspension were added to each of four tubes in a water bath at $38^{\circ} ; 0.25 \mathrm{ml} 20 \mathrm{mM}-\mathrm{H}_{2} \mathrm{O}_{2}$ in buffered saline was added to tubes $\mathrm{A}$ and $\mathrm{B}$ and the same volumes of buffered saline to tubes $\mathrm{C}$ and $\mathrm{D}$. The tubes were then incubated for $\mathrm{I} h$ with continuous mechanical shaking to prevent sedimentation. After incubation, $4.5 \mathrm{ml}$ buffered saline were added to tubes $\mathrm{A}$ and $\mathrm{C}$ and $4.5 \mathrm{ml}$ distilled water to tubes B and D. After centrifuging the tubes at $1000 \mathrm{~g}$ for $10 \mathrm{~min}$, the optical densities of the supernatant liquids were measured at $540 \mathrm{~nm}$. The peroxide haemolysis (\%) was then equal to $\left(\frac{\text { reading of } A}{\text { reading of } B}-\frac{\text { reading of } C}{\text { reading of } D}\right) \times 100$. The blood haemoglobin concentration in $\mathrm{g} / \mathrm{I} / 00 \mathrm{ml}$ was found in calibration experiments to equal fifty-four times the optical density of the aqueous haemolysate in tube $\mathrm{D}$. The packed cell volume was determined with a microhaematocrit centrifuge.

\section{RESULTS}

Most of the results are summarized in Table $\mathrm{I}$.

\section{Group 1 : lambs fed on skim milk containing cod-liver oil}

The mean rate of growth ( $72 \mathrm{~g} /$ day) was significantly less than the $157 \mathrm{~g} /$ day gained by the controls. This was at least partly due to decreased appetite. In 5 weeks, lamb 6 consumed $20 \%$ less food than its sibling, lamb 5 , on a control diet. No clinical symptoms were seen in lamb 85 , which was given $100 \mathrm{mg} \alpha$-tocopheryl acetate by intramuscular injection on days 0,7 and I4. Clinical symptoms were seen in the other four lambs. From day 13 lamb 84 had a decreased appetite, was reluctant to stand up and walked stiffly with its back arched. Lamb 6 had a variable loss of appetite from day I0; muscular weakness, affecting the neck muscles in particular, was evident by day 18 (see Pl. I). Lamb I89 had slight lameness on day 13 ; by day I $_{5}$ its movements had become sluggish and it was reluctant to feed. Lamb I 88 was observed to be lethargic and moving stiffly on over-extended hind fetlock joints on day 22 (see Pl. I) and was unable to rise the next day. The clinical symptoms in these four lambs disappeared within a few days of the intramuscular injection of $200 \mathrm{mg} \alpha$-tocopheryl acetate.

Abnormal increases occurred during the experimental period in the serum enzyme levels of all five lambs except lamb 85 . The increased serum enzyme levels in lambs 84 , 6, 188 and 189 were apparent by 9 days. The results for lambs 188 and 189 , shown in 
Fig. I, are representative of this group of animals except that in lamb 84 there was no increase in GDH and a comparatively small increase in LDH isoenzyme I activity. Values for LDH isoenzymes 2, 3 and 4, which showed increases intermediate between isoenzymes I and 5, are omitted from Fig. I for the sake of greater clarity. After the injections of $\alpha$-tocopheryl acetate there was an exponential decline of the serum enzymes towards normal, with the exception of GDH in lamb 188 . In lamb 6 GDH activity had already returned to normal by the time the injection was given. The half-lives of the other enzymes are shown in Table 2.

Table I. Summary of the abnormalities produced by feeding cod-liver oil and maize oil to lambs, and the therapeutic effects of vitamin $E$

\begin{tabular}{|c|c|c|c|c|c|c|c|c|c|}
\hline \multirow[b]{2}{*}{$\begin{array}{l}\text { Group } \\
\text { no. }\end{array}$} & \multirow[b]{2}{*}{$\begin{array}{c}\text { Lamb } \\
\text { no. }\end{array}$} & Expe & Maize & $\begin{array}{l}1 \text { diet } \\
\text { Cod- } \\
\text { liver }\end{array}$ & Acute & nality pro & $\mathrm{Pduced}^{*}$ & \multicolumn{2}{|c|}{$\begin{array}{c}\text { Treatment } \\
\text { DL- } \alpha \text {-tocopheryl } \\
\text { acetate injections }\end{array}$} \\
\hline & & $\begin{array}{l}(\% \\
w / v)\end{array}$ & $\begin{array}{l}(\% \\
v / v)\end{array}$ & $\begin{array}{l}(\% \\
v / v)\end{array}$ & $\begin{array}{l}\text { dys- } \\
\text { trophy }\end{array}$ & $\begin{array}{l}\text { enzyme } \\
\text { increase }\end{array}$ & $\begin{array}{l}\text { lysis } \\
\text { in vitro }\end{array}$ & $\begin{array}{l}\text { Dose } \\
\text { (mg) }\end{array}$ & $\begin{array}{l}\text { Effect on } \\
\text { abnormality }\end{array}$ \\
\hline I & $\begin{array}{r}6 \\
84 \\
188 \\
189 \\
85\end{array}$ & $\begin{array}{l}20 \\
20 \\
20 \\
20 \\
20\end{array}$ & $\begin{array}{l}\text { nil } \\
\text { nil } \\
\text { nil } \\
\text { nil } \\
\text { nil }\end{array}$ & $\begin{array}{l}5 \\
5 \\
5 \\
5 \\
5\end{array}$ & $\begin{array}{l}++ \\
++ \\
++ \\
++ \\
-\end{array}$ & $\begin{array}{l}++ \\
++ \\
++ \\
++ \\
-\end{array}$ & $\begin{array}{l}- \\
- \\
- \\
-\end{array}$ & $\begin{array}{l}\text { 100 twice } \\
200 \text { once } \\
200 \text { once } \\
200 \text { once } \\
100 \text { weekly }\end{array}$ & $\begin{array}{l}\text { Cured } \\
\text { Cured } \\
\text { Cured } \\
\text { Cured } \\
\text { Prevented }\end{array}$ \\
\hline 2 & $\begin{array}{r}81 \\
190 \\
I \\
82 \\
65\end{array}$ & $\begin{array}{l}20 \\
20 \\
20 \\
20 \\
20\end{array}$ & $\begin{array}{l}5 \\
5 \\
5 \\
5 \\
5\end{array}$ & $\begin{array}{l}\text { nil } \\
\text { nil } \\
\text { nil } \\
\text { nil } \\
\text { nil }\end{array}$ & $\begin{array}{l}- \\
- \\
- \\
-\end{array}$ & $\begin{array}{l}+ \\
+ \\
+ \\
+ \\
+\end{array}$ & $\begin{array}{l}++ \\
++ \\
+t \\
++ \\
++\end{array}$ & $\begin{array}{l}\text { None } \\
\text { None } \\
\text { Ioo twice } \\
\text { roo weekly } \\
5000 \text { twice }\end{array}$ & $\begin{array}{l}\text { Not cured } \\
\text { Not prevented } \\
\text { Not cured }\end{array}$ \\
\hline 3 & $\begin{array}{r}69 \\
68 \\
192\end{array}$ & $\begin{array}{l}20 \\
16 \\
16\end{array}$ & $\begin{array}{l}5 \\
4 \\
4\end{array}$ & $\begin{array}{l}0.5 \\
5 \\
5\end{array}$ & $\begin{array}{l}- \\
++ \\
+t\end{array}$ & $\begin{array}{l}+ \\
++ \\
++\end{array}$ & $\begin{array}{l}- \\
-\end{array}$ & $\begin{array}{l}\text { None } \\
\text { None } \\
\text { None }\end{array}$ & $\dot{.}$ \\
\hline Controls & $\begin{array}{r}2 \\
5 \\
19 \mathrm{I}\end{array}$ & $\dot{.}$ & $\dot{.}$ & $\dot{.}$ & $\overline{-}$ & $\begin{array}{l}- \\
-\end{array}$ & $\overline{-}$ & $\dot{.}$ & $\dot{.}$ \\
\hline
\end{tabular}

* The,+++ and - signs indicate that the abnormality was severe, slight or absent, respectively. $\uparrow \mathrm{DL}-\alpha$-tocopherol by mouth.

In all five lambs there were no abnormal changes in packed cell volume or haemoglobin concentration of blood. Peroxide haemolysis in vitro never exceeded $3 \%$. In the control animals peroxide haemolysis never exceeded $10 \%$.

Serum bilirubin was determined in lambs 188 and $I 89$ and slight increases were observed. Serum potassium was determined by flame photometry in lamb 6. It maintained the same level $(4 \cdot 8-6 \cdot 5$ m-equiv./1.) as the control lamb 5 .

\section{Group 2: lambs fed on skim milk containing maize oil}

None of the five lambs ( $1,81,82,190$ and $\left.6_{5}\right)$ fed on skim-milk containing maize oil developed clinical symptoms of muscular dystrophy, but their mean rate of growth, I $6 \mathrm{~g} /$ day, was significantly less than that of the controls, due at least partly to reduced 
food intake. In 5 weeks lamb I consumed $7 \%$ less food than its sibling, lamb 2 , on the control diet.

There were no obvious increases in serum content of enzymes such as those observed in the lambs fed on cod-liver oil. There appeared to be slight increases in LDH isoenzyme $I$ in lambs 65,82 and $I 90$, but quantitative estimates of activity were not

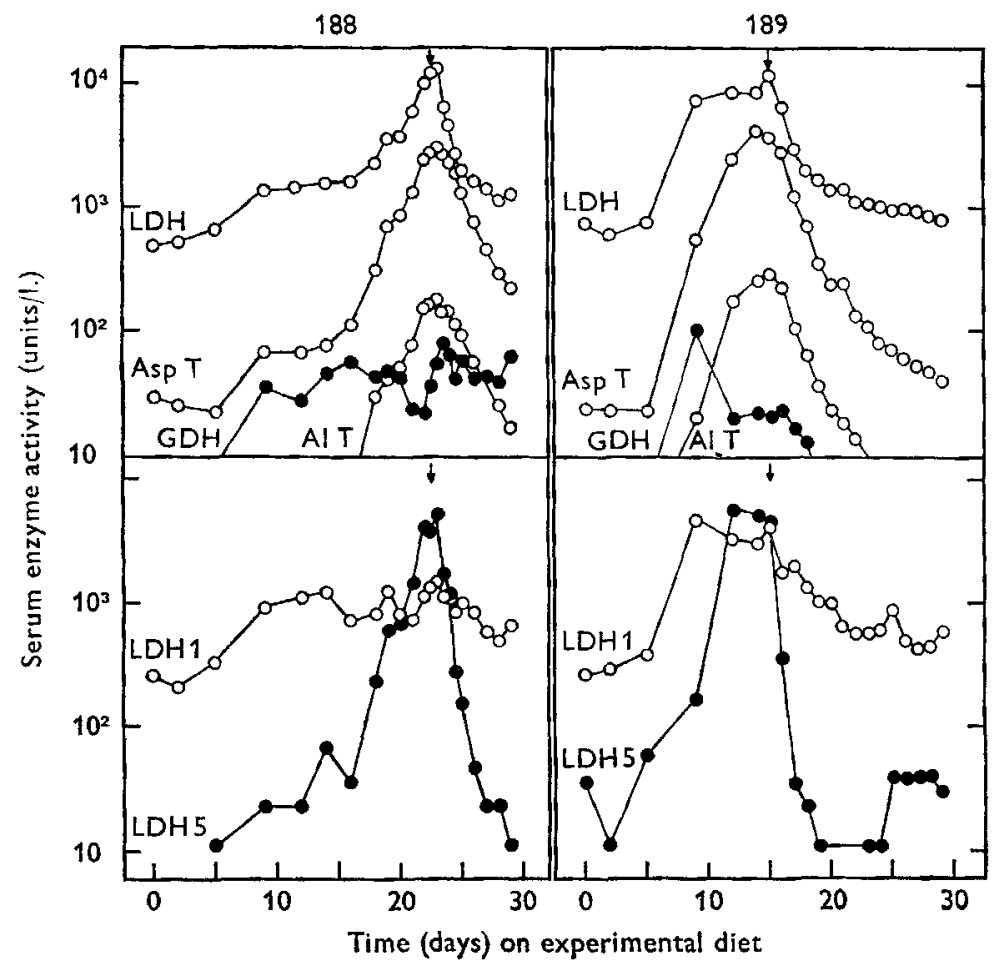

Fig. I. Aspartate transaminase (Asp T), alanine transaminase (Al T), glutamate dehydrogenase $(\mathrm{GDH})$, lactate dehydrogenase $(\mathrm{LDH})$ and $\mathrm{LDH}$ isoenzymes I and 5 in serum of lambs I88 and $\mathrm{I} 89$ fed on milk containing cod-liver oil. The arrows indicate the injection of $200 \mathrm{mg}$ DL- $\alpha$-tocopheryl acetate intramuscularly. Total LDH activity, determined by spectrophotometry, is shown in the upper part and LDH $\mathrm{I}$ and LDH 5 activities, determined by electrophoresis, and densitometry, are shown in the lower part.

Table 2. Mean values, as time for $50 \%$ fall in activity, with their standard errors for the rates at which serum enzymes declined to normal levels in four lambs $(6,84,188$ and 189) during recovery from acute muscular dystrophy, in response to treatment with vitamin $E$

Serum enzyme

Aspartate transaminase

Alanine transaminase

Lactate dehydrogenase isoenzyme I

Lactate dehydrogenase isoenzyme 2

Lactate dehydrogenase isoenzyme 3

Lactate dehydrogenase isoenzyme 4

Lactate dehydrogenase isoenzyme 5
Time (h)

$24.7 \pm 2 \cdot 1$

$31 \cdot 3 \pm \mathbf{I} \cdot 8$

$48 \cdot 6 \pm 12 \cdot 9$

$30 \cdot 8 \pm 3 \cdot 2$

$20 \cdot 0 \pm 3 \cdot 6$

$12 \cdot 6 \pm 2 \cdot 8$

$7.4 \pm 1.8$ 
obtained. The GDH, Asp'T and AlT results were compared statistically with those of the controls. It was observed that the distribution of values was positively skewed and fitted a lognormal curve quite well (Gaddum, r945). Consequently the results were converted into logarithms before the application of Student's $t$ test. This analysis revealed that the Asp T and GDH were significantly elevated, but that AlT was not significantly changed (Table 3).

Table 3. A statistical comparison between serum enzyme activities of lambs fed on milk containing maize oil (group 2) and of lambs in the control group

(The results were transformed into logarithms before statistical analysis because their distribution was lognormal. Alanine transaminase and glutamate dehydrogenase activities expressed in units/10 l., instead of units/1, were used in these calculations in order to avoid negative logarithms. The significance of difference between means was determined by the $t$ test)

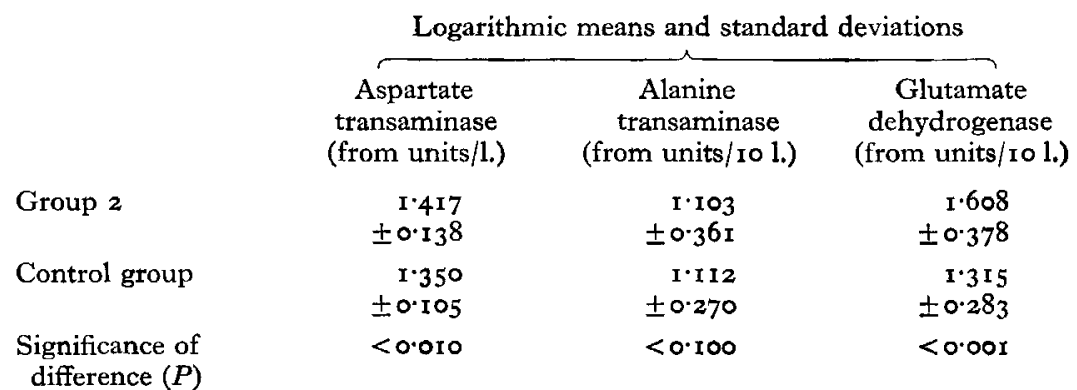

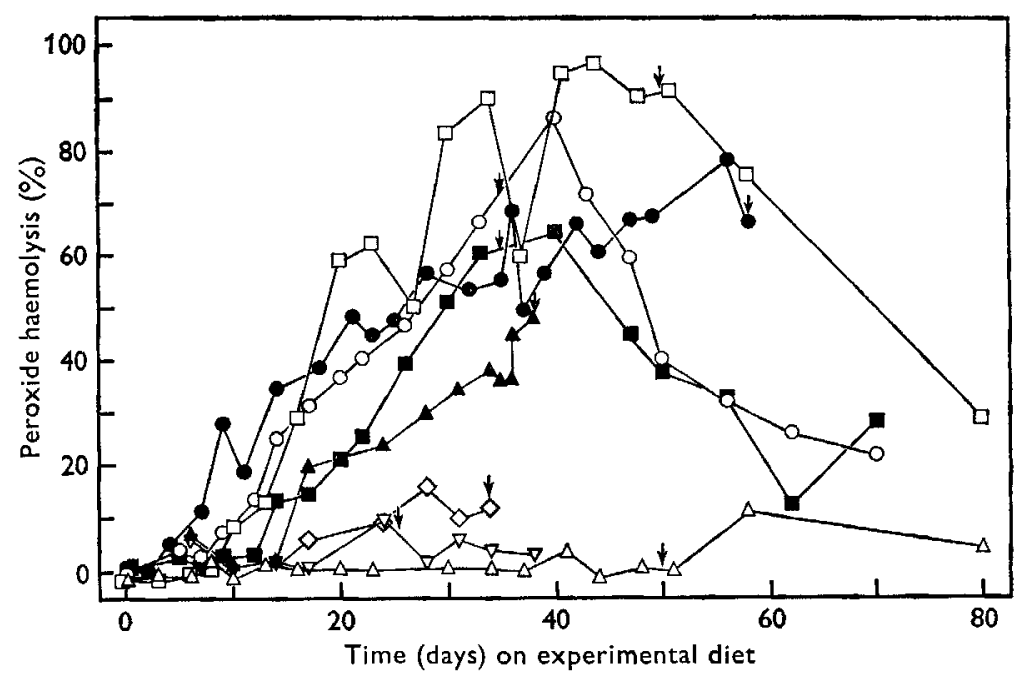

Fig. 2. Peroxide haemolysis in red blood cells from lambs fed on milk containing maize oil. The arrows indicate the time at which the experimental diet was discontinued. Lamb 1,0 ; $81, \bigcirc ; 82, \mathbf{\Xi} ; 190, \square ; 65, \Delta ; 68, \nabla ; 69, \diamond ; 192, \triangle$. Lambs 192,68 and 69 received cod-liver oil as well as maize oil.

In all five lambs there was a marked increase in susceptibility to peroxide haemolysis (Fig. 2). Lamb 82 was given an intramuscular injection of $100 \mathrm{mg} \mathrm{DL}-\alpha$-tocopheryl acetate on days 0,7 and I4. Lamb I was given similar treatment on days $3^{8}$ and 43 . 
Lamb 65 was given $5 \mathrm{~g}$ DL- $\alpha$-tocopherol by mouth on days 34 and 36 . It can be seen in Fig. 2 that these measures neither prevented peroxide haemolysis developing in lamb 82 nor cured it in lambs $x$ and 65 . However, peroxide haemolysis decreased

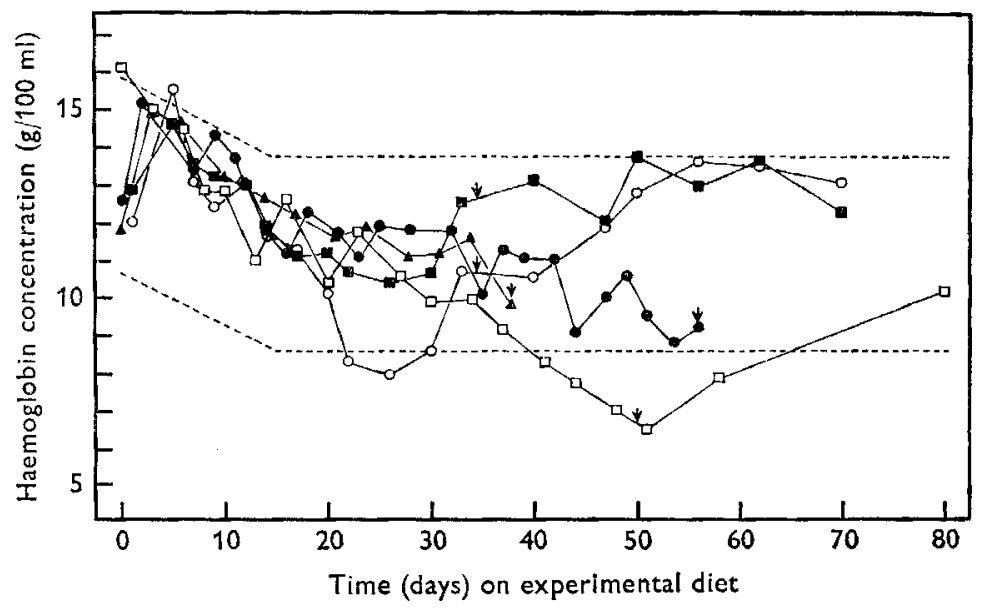

Fig. 3. Blood haemoglobin concentration in lambs given maize oil. The arrows show when the experimental diet was discontinued. Lamb $\mathrm{I}, 0 ; 8 \mathrm{I}, 0 ; 82, \square ; 190, \square ; 65, A$. Dotted lines $=$ mean of controls \pm twice standard error of estimate.

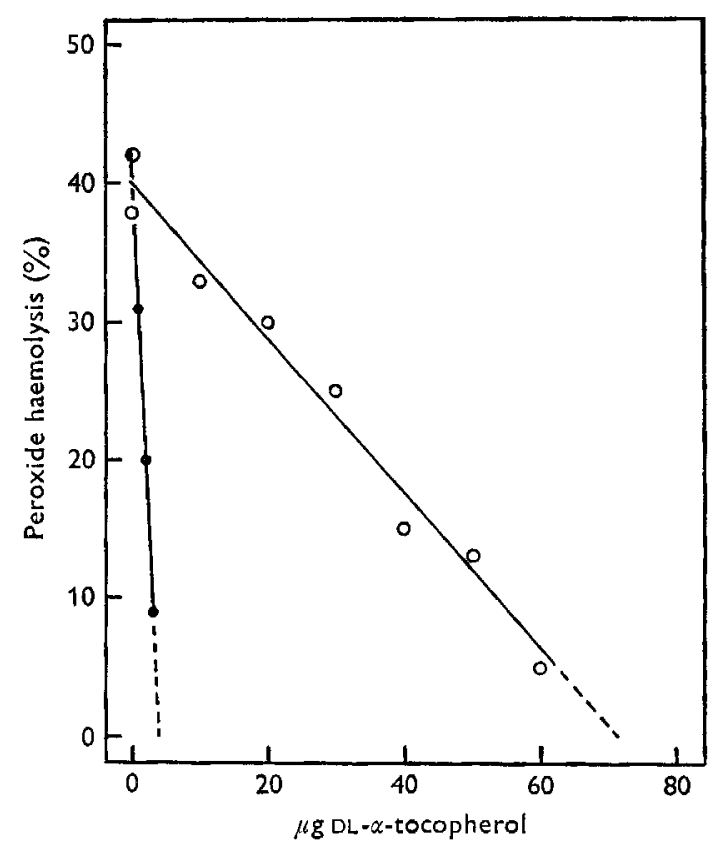

Fig. 4. The effect of added $\alpha$-tocopherol on the peroxide haemolysis test. Varying amounts of $\mathrm{DL}-\alpha$-tocopherol were pre-incubated for $15 \mathrm{~min}$ with $0.25 \mathrm{ml}$ amounts of washed red blood cell suspensions from lamb 65 , before incubating for $\mathrm{I} \mathrm{h}$ with $0.25 \mathrm{ml}$ amounts of hydrogen peroxide solution; $O$, results for lamb 65 ;, results for a human subject described by Horwitt et al. (1956). 
steadily when the diet was changed to one consisting of Ewbol milk replacer, hay and concentrates. When blood haemoglobin concentration was compared with control levels (Fig. 3) it was found that these fell slightly below normal in two animals. The results for packed cell volume were similar to those for haemoglobin concentration.

\section{Group 3: lambs fed on skim milk containing cod-liver oil and maize oil}

The mean rate of growth of lambs 192,68 and 69 ( $118 \mathrm{~g} /$ day) was significantly less than that of the controls. Serum enzymes increased very slightly in lamb 69 , which received only $0.5 \%$ cod-liver oil, but increased markedly in lambs 68 and $192(5 \%$ cod-liver oil). These two lambs showed symptoms of acute muscular dystrophy. Blood haemoglobin concentration fell slightly below normal in all three lambs. Peroxide haemolysis did not increase in any of these lambs (Fig. 2).

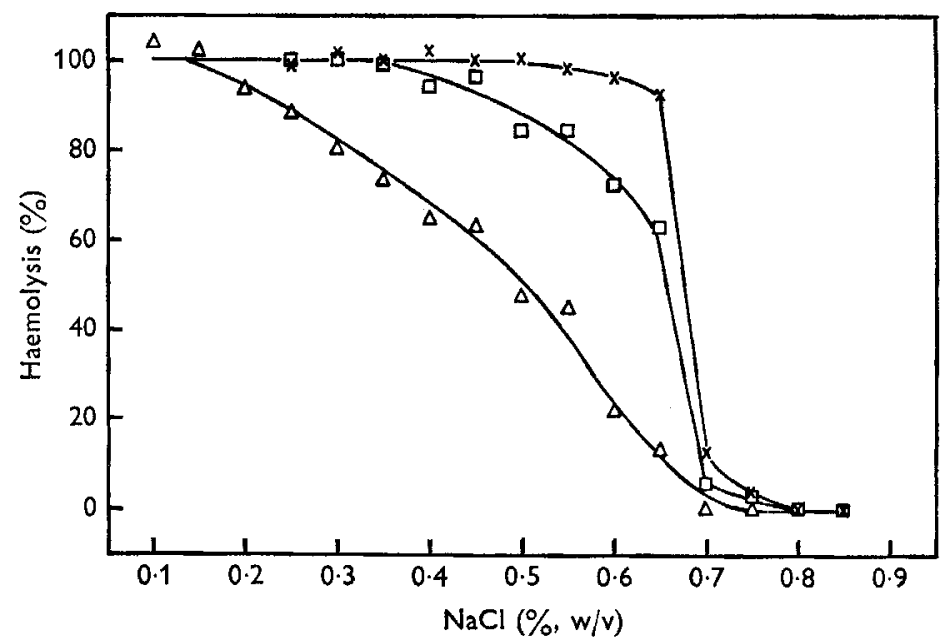

Fig. 5. Osmotic haemolysis of erythrocytes from lamb I9I ( $\times$ ) on a control diet, lamb I90 ( $\square$ ) on a maize-oil diet and lamb $192(\triangle)$ on a diet containing both maize oil and cod-liver oil. The blood samples were collected after 38 days on the experimental diets.

\section{Some experiments in vitro with erythrocytes from lambs fed maize oil}

Erythrocytes from lamb $6_{5}$ were pre-incubated with $\alpha$-tocopherol to see whether this would prevent peroxide haemolysis. Before adding the peroxide in the haemolysis test, the $0.25 \mathrm{ml}$ samples of the washed erythrocyte suspensions from lamb 65 were pre-incubated for $\mathrm{I}_{5} \mathrm{~min}$ at $38^{\circ}$ with $2-\mathrm{I} 2 \mu 1$ samples of a $0.5 \%(\mathrm{w} / \mathrm{v})$ emulsion of DL- $\alpha$-tocopherol in $60 \%(\mathrm{v} / \mathrm{v})$ aqueous ethanol. The results are plotted in Fig. 4 alongside comparable results obtained by Horwitt et al. (1956), who used erythrocytes from a vitamin E-depleted human subject.

Erythrocytes from lambs I90, I9I and I92 collected on days 38 and 87 were tested for osmotic fragility by suspending them in a series of hypotonic saline solutions. The percentage haemolysis was calculated from the spectrophotometer readings at $540 \mathrm{~nm}$ after centrifuging to remove the surviving erythrocytes. The results for day $3^{8}$ are shown in Fig. 5. Microscopic examination revealed that the erythrocytes from lambs 
190 and 192 were thinner than normal, especially those of 192 , which were typical target cells with a distinct pale central area. By day 87 the shape and osmotic resistance of erythrocytes of lambs 190 and 192 had almost returned to normal.

\section{Post-mortem examination of skeletal muscle}

(from lambs 1, 6, 84, 85, 188 and 189)

No abnormalities were detected in the muscles of lamb $\mathrm{I}$, given the maize-oil diet and examined post mortem at the end of the experiment. The tissues of the lamb 85 which was fed on the cod-liver oil diet and received prophylactic vitamin $\mathrm{E}$ were also normal.

Sections of muscle regenerating after vitamin E treatment are shown in P1. 2 alongside degenerating muscle from an untreated lamb in an earlier experiment (Boyd, I964). The sections in Pl. $2(c)$ and (d) are from muscles at an early stage of regeneration, 6 days after treatment. The sections in $(e)$ and $(f)$ are from muscles at a late stage of regeneration, 14 and 19 days after treatment.

\section{DISCUSSION}

\section{Serum enzyme changes}

The increases in serum enzyme content in lambs with muscular dystrophy induced by dietary cod-liver oil correspond to those reported in previous experiments (Boyd, I964). Since muscle is relatively rich in $\mathrm{AlT}$ the increases in serum $\mathrm{Al} T$ were attributed to leakage from degenerating muscle. The slight increases in serum bilirubin and transient increases in serum GDH were attributed to damage to GDH-rich hepatic tissue.

Both Asp T and LDH occur widely in all tissues. The Asp T isoenzyme patterns of different tissues are very similar (Boyd, rg66) but there are marked tissue variations in $\mathrm{LDH}$ isoenzyme patterns (Boyd, 1964). All five isoenzymes of $\mathrm{LDH}$ are present in skeletal muscles but isoenzyme 5 usually predominates. The electrophoretically fastmoving isoenzymes, especially $\mathrm{LDH} \mathrm{r}$, predominate in liver and heart, so damage to these organs may contribute to their high activities in the serum of dystrophic animals. However, even allowing for LDH releases from tissues other than skeletal muscle, the proportion of fast-moving isoenzymes in serum is surprisingly high. There are no marked increases in the proportion of fast-moving isoenzymes in the muscles of dystrophic lambs (Boyd, I964; Paulson, Pope \& Baumann, I966) such as have been reported in human patients (Wieme \& Herpol, 1962). The probable explanation for the $\mathrm{LDH}$ isoenzyme pattern is differential clearance of $\mathrm{LDH}$ isoenzymes from plasma, since injected purified $\mathrm{LDH}_{5}$ disappears from the plasma of lambs much more rapidly than $\mathrm{LDH}$ I (Boyd, I967) and the rates of disappearance of $\mathrm{LDH}$ isoenzyme from plasma after vitamin $\mathrm{E}$ treatment of dystrophic lambs decreased progressively from $\mathrm{LDH}_{5}$ to $\mathrm{LDH}_{\text {I }}$ (Table 2). It has been calculated that $\mathrm{LDH}_{5}$ must be released from tissues $75^{-15}$ times faster than LDH $I$ in order to maintain the same level in plasma (Boyd, 1967).

The serum enzyme results confirm the clinical observation that injections of 
$\alpha$-tocopheryl acetate both prevent and rapidly cure acute muscular dystrophy induced by feeding cod-liver oil to lambs. According to Paulson et al. (1966), vitamin E given orally is also effective in curing and preventing muscular dystrophy and associated serum enzyme increases in lambs given a diet containing stripped lard. Kuttler \& Marble (1960) reported that vitamin E, but not selenium, prevented muscular dystrophy in lambs given cod-liver oil.

Muscular dystrophy has been induced in rats (Century \& Horwitt, 1960) and pigs (Thafvelin, I960) by diets containing maize oil which had been processed to remove vitamin $\mathrm{E}$. Since vitamin $\mathrm{E}$ was added during manufacture of the maize-oil diet used in the present work, it is not surprising that muscular dystrophy was not induced. However, food intake and growth rates were reduced and there were slight but significant increases in serum Asp T and GDH but not in AlT. This serum pattern is consistent with slight liver damage (Boyd, 1962, 1964); though why this should occur is obscure, because serum enzyme increases were not prevented in lamb 82, or cured in lamb I by vitamin E. In this connexion it appears that the GDH increases in the lambs given cod-liver oil are independent of muscular dystrophy and vitamin $\mathrm{E}$ therapy since they are often transient as in lambs 6 and I89, while in lamb 84 no increase was observed at all and in lamb 188 the serum GDH did not decline after vitamin $\mathrm{E}$ therapy. The increases in $\mathrm{LDH} \mathrm{I}$, which appeared to accompany the GDH increases, are consistent with the hypothesis that this isoenzyme is being released from liver.

\section{Susceptibility to haemolysis by hydrogen peroxide in vitro}

Haemolysis in vitro by dialuric acid or hydrogen peroxide has been used as an index of vitamin E deficiency. Rose \& György (1952) showed that treating deficient rats with vitamin $\mathrm{E}$ or pre-incubating their erythrocytes with vitamin $\mathrm{E}$ prevented the haemolysis. Erythrocytes of human adults maintained on a vitamin E-deficient diet for long periods are susceptible to peroxide haemolysis until plasma tocopherol levels return to normal after treatment with vitamin $\mathrm{E}$ (Horwitt et al. 1956), but Horwitt (I960) observed that it was difficult to restore peroxide haemolysis to normal by vitamin E supplementation in men given maize oil, freed from vitamin E. Hopkins, Pope \& Baumann (1964) reported that dialuric acid haemolysis was increased in dystrophic lambs and returned to normal when they were given $40-50 \mathrm{mg}$ tocopherol per week. In the present study it was surprising that peroxide haemolysis was not increased in the erythrocytes of dystrophic lambs given cod-liver oil, whereas it was observed in the erythrocytes of lambs given maize oil, although muscular dystrophy did not develop in the latter. This increase in peroxide haemolysis was neither cured nor prevented by doses of $\alpha$-tocopheryl acetate that were effective against muscular dystrophy in the lambs given cod-liver oil. Large amounts of $\alpha$-tocopherol were required to be added in vitro to prevent haemolysis of erythrocytes of lamb 65 . The increased peroxide haemolysis did slowly return to normal when lambs 81,82 and 190 were weaned from the maize-oil diet. Lambs that were given both maize oil and cod-liver oil showed no increased peroxide haemolysis, and erythrocytes from at least one lamb (192) showed an increased resistance to osmotic haemolysis. Thus the feeding of cod- 
liver oil appeared to inhibit the increase in susceptibility to peroxide haemolysis induced by maize oil. This result can be compared to the finding of Century \& Horwitt (1959) that dietary cod-liver oil inhibited the occurrence of encephalomalacia induced by feeding maize oil to chicks. Dam, Nielsen, Prange \& Søndergaard (1958) found that arachidonate, and linoleate, after conversion into arachidonate in the body, induced encephalomalacia in chicks, whereas linolenate did not. Century, Witting, Harvey \& Horwitt ( 1963 ) found that the brain lipids of chicks fed cod-liver oil were low in arachidonic acid, presumably because the linolenic acid of the cod-liver oil inhibited the conversion of linoleic acid into arachidonic acid. The encephalomalacia seemed to be associated with the deposition of abnormally large amounts of arachidonic acid in the brain lipids. The prophylactic effect of cod-liver oil could be attributed to suppression of the accumulation of arachidonic acid. Similarly, dietary linolenic acid suppresses the arachidonic acid concentration in the lipids of rat erythrocytes (Mohrhauer \& Holman, 1963). Hence rats given maize oil have a high proportion of arachidonic acid in their erythrocyte lipids and those given cod-liver oil have abnormal amounts of pentaenoic acid (Witting, Harvey, Century \& Horwitt, 196r). There is evidence that the erythrocyte lipids of lambs are subject to similar alteration by dietary lipids (De Gier \& Van Deenen, 1964). The slow rate at which peroxide haemolysis returns to normal after the diet is changed is consistent with the hypothesis that it depends on a gradual dilution and replacement of erythrocytes containing an excessive amount of unsaturated fatty acids by normal cells.

Thus both encephalomalacia in chicks and peroxide haemolysis in lambs may depend on arachidonic acid deposition, although there is no obvious reason why arachidonic acid in brain and erythrocytes should be more susceptible to auto-oxidation in vitamin E deficiency than is pentaenoic acid. Certainly muscular dystrophy will result from dietary cod-liver oil, which is known to cause the accumulation of pentaenoic acid in skeletal muscle as well as in erythrocytes and brain (Century, Witting, Harvey \& Horwitt, I96r). Perhaps, after all, the harmful effects of unsaturated dietary lipids are not due to their peroxidation in the tissues, but are the result of some other unknown process that may also involve vitamin E (Green, Diplock, Bunyan, McHale \& Muthy, $1967)$.

The vitamin $\mathrm{E}$ in the diet containing both maize oil and cod-liver oil was not sufficient to prevent muscular dystrophy in lambs 192 and 68, although as little as I00 $\mathrm{mg} \alpha$-tocopheryl acetate intramuscularly per week prevented dystrophy in lamb 85 . There is, however, not sufficient evidence to suggest whether the reduced appetite, retarded growth and increased serum enzymes in lambs given this diet were due to deficiency of vitamin $\mathrm{E}$ or of some other essential nutrient, or to a toxic effect of unsaturated fatty acid. It must be pointed out that the adverse effects on lambs of the baby food containing maize oil may not apply to the human infant. It is possible, for instance, that there is greater destruction of dietary vitamin $\mathrm{E}$ in the gastro-intestinal tract of the young ruminant than in that of the human infant.

The technical assistance of R. Braham is gratefully acknowledged. 


\section{REFERENCES}

Boyd, J. W. (г962). Res. vet. Sci. 3, 256.

Boyd, J. W. (I964). Res. vet. Sci. 5, 419.

Boyd, J. W. (I966). Biochim. biophys. Acta 113, 302.

Boyd, J. W. (1967). Biochim. biophys. Acta r32, 22 r.

Century, B. \& Horwitt, M. K. (1959). Proc. Soc. exp. Biol. Med. 102, 375.

Century, B. \& Horwitt, M. K. (1960). F. Nutr. 72, 357.

Century, B., Witting, L. A., Harvey, C. C. \& Horwitt, M. K. (196r). F. Nutr. 75, 341.

Century, B., Witting, L. A., Harvey, C. C. \& Horwitt, M. K. (I963). Am. F. clin. Nutr. I3, 362.

Dam, H., Nielsen, G. K., Prange, I. \& Søndergaard, E. (1958). Nature, Lond. r82, 802.

De Gier, J. \& Van Deenen, L. L. M. (1964). Biochim. biophys. Acta 84, 294.

Gaddum, J. H. (1945). Nature, Lond. 156, 463.

Green, J., Diplock, A. T., Bunyan, J., McHale, D. \& Muthy, I. R. (I967). Br. F. Nutr. 2 I, 69.

Harris, P. L. \& Embree, N. D. (1963). Am. F. clin. Nutr. 13, 385 .

Hassan, H., Hashim, S. A., Van Itallie, T. B. \& Sebrell, W. H. (1966). Am. F. clin. Nutr. I9, I47.

Hopkins, L. L. Jr, Pope, A. L. \& Baumann, C. A. (1964). F. Anim. Sci. 23, 674.

Horwitt, M. K. (1 960). Am. J. clin. Nutr. 8, 45 I.

Horwitt, M. K., Century, B. \& Zeman, A. A. (1963). Am. F. clin. Nutr. r2, 99.

Horwitt, M. K., Harvey, C. C., Duncan, G. D. \& Wilson, W. C. (1956). Am. F. clin. Nutr. 4, 408.

Kuttler, K. L. \& Marble, D. W. (r 960). Am. F. vet. Res. 21, 437.

Mohrhauer, H. \& Holman, R. T. (1963). F. Nutr. 81, 67.

Paulson, G. D., Pope, A. L. \& Baumann, C. A. (1966). Proc. Soc. exp. Biol. Med. 122, 32 1.

Rose, C. S. \& György, P. (1952). Am. F. Physiol. 168, 4 I4.

Thafvelin, B. (1960). Nature, Lond. 188, I I69.

Wieme, R. J. \& Herpol, J. E. (1962). Nature, Lond. 194, 287.

Witting, L. A., Harvey, C. C., Century, B. \& Horwitt, M. K. (r96r). J. Lipid Res. 2, 412.

\section{EXPLANATION OF PLATES}

\section{Plate I}

Lambs with acute muscular dystrophy induced by the cod-liver oil diet. Upper: lamb i 88 after 22 days, with collapse of the hind fetlocks. Lower; lamb 6 after 18 days, with severe muscular weakness especially of the neck muscles.

\section{Plate 2}

Photomicrographs of dystrophic skeletal muscles from lambs.

(a) Lamb $T_{3}$ (from Boyd, 1964). LS of flexor carpi radialis muscle. Haematoxylin and eosin stain. A degenerating muscle fibre, myoblasts and myotubes.

(b) Another section from the same specimen. Von Kossa stain. Calcification in muscle fibres.

(c) Lamb 84, LS of gastrocnemius. Haematoxylin and eosin stain. Myoblasts and regenerating muscle fibres.

(d) Lamb 188, TS of vastus medialis. Haematoxylin and eosin stain. Calcified muscle fibres and regenerating muscle fibres.

(e) Lamb 189 , LS of lateral digital. Haematoxylin and eosin stain. Large vacuolar nuclei in some fibres.

(f) Lamb 6, LS of a dorsal neck muscle. Haematoxylin and eosin stain. Many large nuclei and many pale-staining muscle fibres. 
British fournal of Nutrition, Vol. 22, No. 3

Plate I
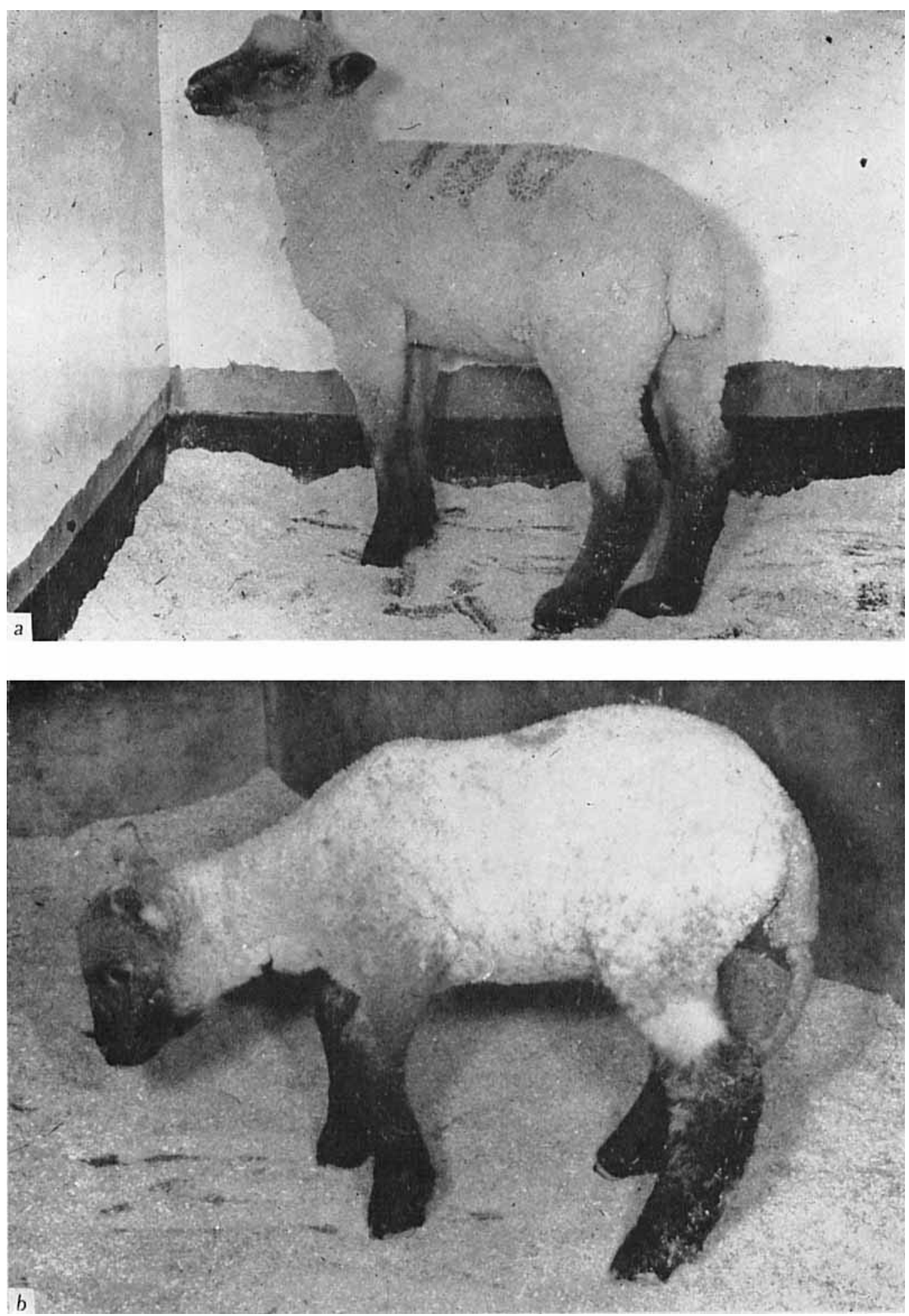

J. W. BOYI)

(Facing p. 422) 

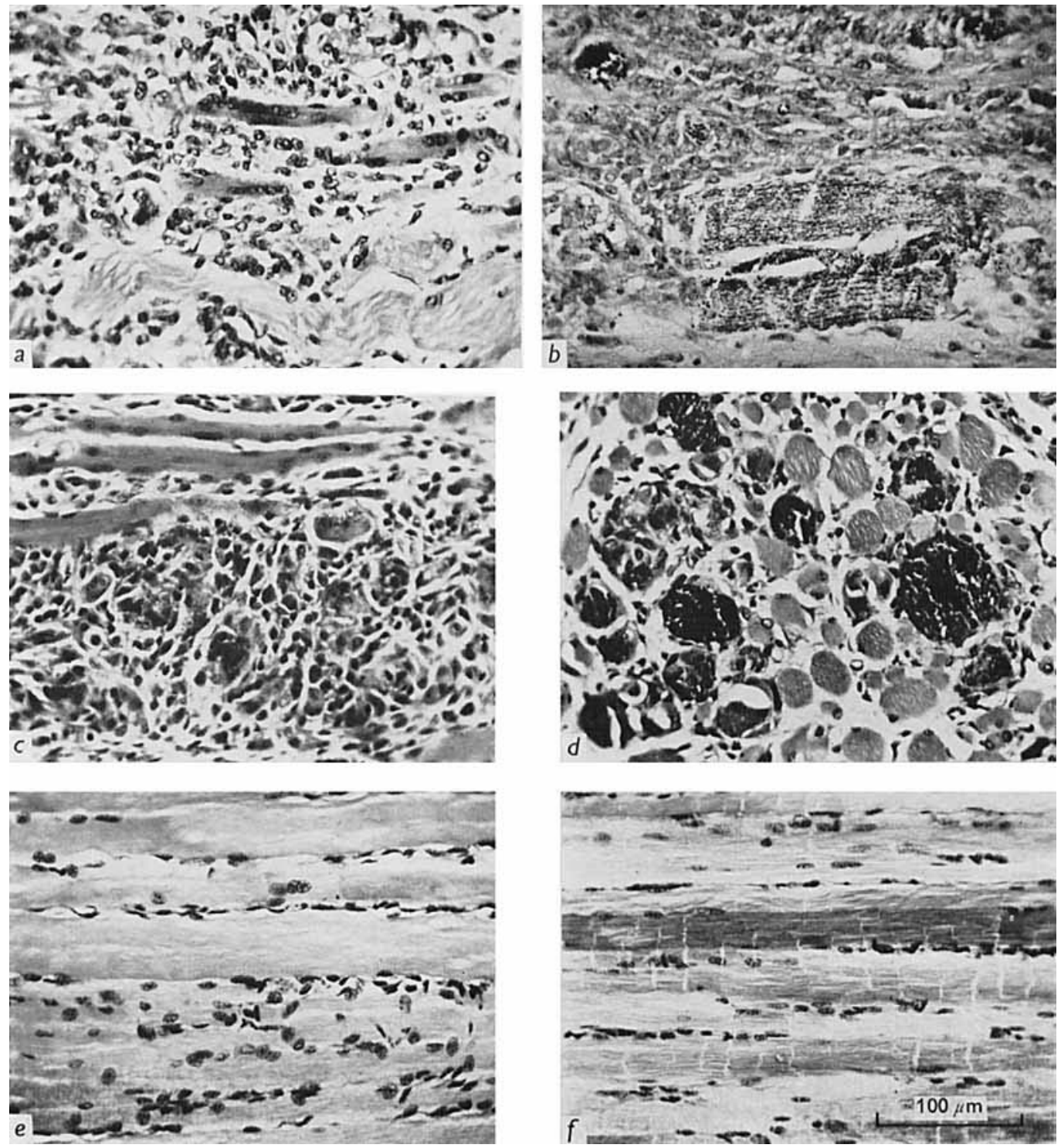

J. W. BOYD 